\title{
Ownership Concentration and Going Concern: Evidence from Jordanian Listed Firms
}

\author{
Mohammed Hassan Makhlouf ${ }^{1} \&$ Fares Jamiel Al-Sufy $^{1}$ \\ ${ }^{1}$ Faculty of Business, Isra University, Amman, Jordan \\ Correspondence: Mohammed Hassan Makhlouf, Faculty of Business, Isra University, Amman 11622, Jordan. \\ E-mail: mohammed.makhlouf@iu.edu.jo
}

Received: June 19, 2018

Accepted: July 25, 2018

Online Published: August 1, 2018

doi:10.5539/ijbm.v13n9p139

URL: https://doi.org/10.5539/ijbm.v13n9p139

\begin{abstract}
This study aims to investigate whether ownership concentration affects the going concern. The study depends on a panel data set drawn from 100 non-financial firms listed on the Amman Stock Exchange (ASE) for the period from 2013 to 2016. Ownership concentration was characterized by family ownership and board of directors' ownership. Going concern was measured using Altman's Z-Scores Model (1968). The outcomes report that the family ownership and directors' ownership are positively associated with going concern. This study presents worthy insights to the understanding of ownership types that may influence going concern evaluation among Jordanian companies. Thus, the results of this article introduce substantial conclusions for investors, policymakers and academics to shed the light on the ownership types that enhance the continuity of firms.
\end{abstract}

Keywords: Ownership concentration, Family ownership, Board of directors' ownership, going concern, Jordan

\section{Introduction}

At the beginning of $21^{\text {st }}$ century, a wave of accounting scandals has swept across financial markets and major firms throughout the world, such as the Enron Inc. in 2001, Word Com Inc. in 2002 and Arthur Anderson in 2002 as well as other high-profile crises such as global financial crisis of 2008 and Dubai crisis of 2009. These scandals and crises have influenced the investors and stakeholders trust of financial statements. Moreover, the aftermath findings of these scandals and crises alerted the attention of both regulators and researchers to the importance of financial statements quality and the importance of application of accounting principles such as going concern principle (Q. Zureigat, 2011). In general, the application of the going concern principle and other accounting principles ensures that financial statements are both useful and reliable. Going concern principle represents one of the crucial accounting principles which state that the financial statements have been prepared depending on the likelihood of the firm continuing its normal business to infinity.

In developing countries, companies are characterized as having a more concentrated ownership structure in which family ownership is more popular (Al Dubai, Ismail, \& Amran, 2014; Watkins-Fassler, Fernández-Pérez, \& Rodríguez-Ariza, 2017). Ownership concentration refers to the proportion of firm's stock owned by a certain number of institutions, individuals or families (Oluku, 2017). "Previous studies show that ownership concentration is correlated with company going-concern (e.g., Noor Amran \& Ahmad, 2010; Oluku, 2017; Ramadan, 2016). Oluku (2017) concludes that the firm's going concern depends on its ownership structure. Sunusi Garba (2017) points out that the managers who have a major ownership in a firm are unlikely to participate in the elusive work that may affect the firm's going-concern. Moreover, agency theory argues that concentrated ownership (i.e., family ownership, directors' ownership) may reduce the interests' conflicts between the managers as agent and shareholders as principal, which may mitigate the agency costs and improves the corporate performance and enhance going concern principle. Thus, the association between the concentrated ownership and going concern is significant. "Consequently, the aim of this paper is to explore whether the ownership concentration affects the going-concern of Jordanian listed firms.

Jordanian economy represents an "institutional setting characterized by the existence of high ownership concentration levels across most of the companies listed on Amman stock exchange that are controlled by ownership concentrated (i.e. family ownership) (Haddad, AlShattarat, AbuGhazaleh, \& Nobanee, 2015; Makhlouf, Al-Sufy, \& Almubaideen, 2018; Makhlouf, Laili, Ramli, \& Basah, 2017). Haddad et al. (2015) points out that Jordanian companies are characterized by the concentrated of ownership in the hands of family members 
and dominance of family members on the board of directors. This type of control means that agency conflicts among the family board members and the minority shareholders are more severe in Jordanian companies (Haddad et al., 2015), and this may affect firm performance and going concern evaluation. Makhlouf et al. (2017) points out that $23 \%$ of boards' seats are dominated by families' members who hold $25 \%$ of firms' stock, while $46 \%$ of the companies' stocks are in the hands of the members of the board of directors."

The importance of this research arises from the lack of similar studies of the relationship of ownership concentration and going concern in developing economies in general, and particularly in Jordan. Moreover, previous studies have focused on some kinds of ownership concentration, such as large shareholders, managerial ownership and institutional ownership with little attention paid to the importance of other kinds of ownership structure such as family ownership and directors' ownership. To the best of my knowledge, there is one other study that discusses the association between ownership structure and going concern in Jordan, that of conducted by (B. Zureigat, Fadzil, \& Ismail, 2014b). But our study is different from B. Zureigat et al. (2014b) study by using a large sample of panel data and depending a group of control variables in order to clarify the relationship between the concentration of ownership and going concern. Moreover, besides examining directors' ownership, this research looks at the effect of family ownership on going concern, which was not investigated by previous studies in the Middle East countries, and particularly in Jordan. Thus, this study seeks to fill this gap by examining the impact of concentrated ownership represents by family ownership and director's ownership on firms' going concern.

The reminder of this paper is prepared as follows: section two presents a summary of the previous related literature, section three discusses the data and methodology used by this study. Section four reports the empirical findings and section five presents the conclusions.

\section{Literature review}

\subsection{Family Ownership and Going Concern}

The phenomenon of "family-controlled companies is common in emerging markets where the majority of listed companies are controlled by family members (Haddad et al., 2015; Makhlouf et al., 2017; Warrad, Almahamid, Slihat, \& Alnimer, 2013). Chen, Gray, and Nowland (2011) argues that family ownership mitigates the clashes between the managers and shareholders due to the separation between the management and owners, which may enhance the firm performance and gives the power to the board of directors to monitor managerial behaviour to protect the shareholders' rights. Moreover, companies with high concentration of family ownership often have longer time horizons compared to other companies because the family members have a desire to move the wealth for the following generations, and thus they are seek to draw strategic plans and ideas to ensure that the company is able to continue in the future (Anderson \& Reeb, 2004). On the other hand, the second type of agency problem is widespread in family-controlled firms, which commonly appears as an outcome of conflicts between the majority (e.g., family control ownership) and minority shareholders (Dyer, 2006; Habbash, 2010). Under this type of agency conflicts, "family members have the authority to control the company in a way that maximizes their private interests and expropriate the interests of minority shareholders (Haddad et al., 2015).

From stewardship theory perspectives, "the existence of family members on the board of directors is able to provide great benefits to a firm's continuity, especially if family ownership is combined with family participation on the board of directors, in this case the family members will be able to introduce a long-term vision of wealth creation because they understand the company better than outside CEOs and they are able to introduce an eligible decisions because they spend their working lives in the company they manage" (Chen et al., 2011).

Despite that the family firm phenomenon is widespread in developing countries, to date; very few studies have examined the relationship between the family control and going concern evaluation. In Spain, Pedro Sánchez Ballesta and Garcia-Meca (2005) examined the effect of family control on audit report by using a sample of firms listed on the Madrid Stock Exchange during the period 1999-2002. The outcomes indicate that there is a positive and significant relationship between the concentration of family ownership on the going concern opinion issuance. Their outcomes imply that the auditor can provide quality audit even though they work in conditions where family owners are extremely dominant. Moreover, this result is inconsistent with agency theory perspective which assumes that high level of family control is correlated with lower level of board independence and makes auditors tend to issue going concern opinion. In Jordan, using a sample of 226 companies listed in Amman stock exchange for a period of five years from 2011-2012, B. Zureigat et al. (2014b) examined the relationship between foreign, family ownership and audit committee on the going concern evaluation. The findings indicate that there is a significant but negative relationship between family ownership and firm's going concern. Our study is different from B. Zureigat et al. (2014b) study by focusing on a panel data large sample 
and using a group of control variables in order to clarify the relationship between the concentration of ownership and going concern. Hence, based on the above discussion, this study hypothesizes that:

H1: There is a positive relationship between the family ownership and going concern.

\subsection{Board of Director's Ownership}

Accounting principles suggest that there should be a separation between the ownership and control of listed companies (Stigler \& Friedland, 1983). As a result of this separation, a conflict of interests among shareholders and managers has appeared (Bathula, 2008). This conflict arises because the goals of owners (shareholders) and management (managers) are different. For instance, owners seek to maximize their wealth and improve firm value, while managers aim to increase their own wealth at the expense of the company's and the stockholders' interests (Fama \& Jensen, 1983), as a result of this difference in goals between shareholders and managers appears the agency problem. To solve the conflict of interests between managers and shareholders, Davis, Schoorman, and Donaldson (1997) suggest adopting the alignment hypothesis. Alignment hypothesis suggests that the company should grant some of shares to the managers; this way may lead to aligning managers' interests with shareholders' interests. Previous studies (e.g., Becht, Bolton, \& Röell, 2002; Fama \& Jensen, 1983; Jensen \& Meckling, 1976) pointed out that the directors' ownership gives the board members superior incentives to enhance effective monitoring of the company's management and enhance the firm's continuity. Moreover, aligning interests between the shareholders and managers reduces the opportunistic behaviour for managers.

In this context, Horner (2010) argues that at weak levels of equity ownership, directors will choose to separate the roles of CEO and chairman but conversely they will choose to merge these roles if their ownership increases. From the corporate governance perspective, directors' ownership is considered one of the corporate governance mechanisms that could be a possible solution to the agency problem by aligning the objectives of directors and shareholders.

Previous studies addressed the relationship between directors' ownership and going concern. Hashim (2009) argues that the relationship between directors' ownership earnings quality is significantly and negatively, which directly maximizes earnings management and then leads to a going-concern problem. Elsayed (2007) finds a positive and significant relationship between directors' ownership and firm performance which will decline the risks of the going-concern problem. In Jordan, B. Zureigat et al. (2014b) points out that the association between executive ownership and going-concern problem is positive.

In Malaysia, Ali, Salleh, and Hassan (2008) and Iskandar, Rahmat, Noor, Saleh, and Ali (2011) found that directors' ownership negatively affect the earnings management which will sequentially decrease a going-concern problem. Using a sample of 161 financially distressed companies for the period 1988-1996, Parker, Peters, and Turetsky (2005) examined the relationship of corporate governance factors and going concern assessments in Portugal. Their results indicate that managers' ownership is negatively correlated with going-concern evaluations. This finding is consistent with Alves (2012); Alzoubi (2016) and Ramadan (2016). In Jordan, Makhlouf et al. (2017) examined the association between directors' ownership and firm performance for a panel of 120 of Jordanian companies. The findings indicate that the relationship is positive and significant. The authors argued that this result implies that the increase in directors' ownership enhances the firm's continuity and improves the performance. Hence, based on the above discussion, this study hypothesizes that:

$\mathrm{H} 2$ : There is a positive relationship between the directors' ownership and going concern.

\section{Methodology}

\subsection{Sample and Data Collection}

The sample of this paper covers two sectors of firms listed on ASE: industry and services sectors, which together represent more than $50 \%$ of Jordanian listed firms. The final sample is 100 companies. The study covers the years 2013 to 2016. This study depends on annual reports to extract the appropriate data and measure the study variables. Therefore, secondary data was used as the major source of data.

\subsection{Variables Measurements}

\subsubsection{Going Concern (GC)}

To evaluate the firm's going concern, Altman's Z-Scores Model (1968) has been used in this study. Altman classifies the companies into three groups as "strong if $\mathrm{Z}$ rate is $>2.99$, moderate if $\mathrm{Z}$ rate is between 1.811 and 2.98 and weak if $Z$ rate is $<1.811$ " (Altman, 1968). Moreover, Altman's Model depends on financial ratios to evaluate the firm's going concern. Thus, this study depends on five of Altman's ratios to calculate the Z-Score;

$$
\text { Zscore }=1.2 \mathrm{WC} / \mathrm{TA}+1.4 \mathrm{RE} / \mathrm{TA}+3.3 \mathrm{EBIT} / \mathrm{TA}+0.6 \mathrm{MV} / \mathrm{BV}+1.0 \mathrm{Sales} / \mathrm{TA}
$$


Where

$$
\begin{array}{ll}
\mathrm{Z} \text { score } & =\text { Financial condition of the firm (strong, moderate and weak) } \\
\mathrm{WC} / \mathrm{TA} & =\text {. Working capital } / \text { total asset } \\
\mathrm{RE} / \mathrm{TA} & =\text { Retained earnings } / \text { total asset } \\
\mathrm{EBIT} / \mathrm{TA} & =\text { Earnings before interest and tax / total asset } \\
\mathrm{MV} / \mathrm{TA} & =\text { Market value of share } / \text { book value of debt } \\
\mathrm{SA} / \mathrm{TA} & =\text { Sales } / \text { total asset }
\end{array}
$$

\subsubsection{Ownership Concentration}

In this study, independent variable is the ownership concentration, which is measured by family ownership and board of directors' ownership.

\subsubsection{Family ownership (FOWN)}

FOWN is computed as the percentage of family ownership to total shares of the company. This variable has been used in numerous of prior studies (e.g., Chen et al., 2011).

\subsubsection{Board of directors' ownership (BOWN)}

BOWN is calculated as the percentage of ownership of board of directors to total shares of the company. This variable has been used in numerous of previous studies (e.g., Vo \& Phan, 2013; Warrad et al., 2013).

\subsection{Control Variables}

In addition to independent variables, there are some control variables have been used in this research such as firm size, firm age and leverage. Firm size is measured by a natural log of total assets. Firm age is measured by the average of the age of firm. Leverage equals the ratio of total liabilities divided by total assets.

Table 1. Variables definition

\begin{tabular}{lll}
\hline Variables & Acronym & Measurements \\
\hline $\begin{array}{l}\text { Dependent variable } \\
\text { Going concern }\end{array}$ & GC & Zscore = "1.2 WC/TA + 1.4 RE/TA + 3.3 EBIT/TA + 0.6 MV/BV + 1.0 Sales/TA" \\
$\begin{array}{lll}\text { Independent variables } \\
\text { Family ownership }\end{array}$ & FOWN & percentage of family ownership to total shares of the company \\
$\quad$ Board of directors' ownership & BOWN & percentage of directors' ownership to total shares of the company \\
Control variables & & \\
Firm Size & FS & Natural log of total assets \\
Firm age & FA & Average of the age of firm \\
Leverage & LV & Total liabilities divided by total assets \\
\end{tabular}

\subsection{Model Specification}

To study the impact of ownership concentration on firm's going concern, this study used the following panel data regression model:

Where:

$$
\mathrm{GC}_{\mathrm{it}}=\beta_{0}+\beta_{1} \mathrm{FOWN}_{\mathrm{it}}+\beta_{2} \mathrm{BOWN}_{\mathrm{it}}+\beta_{3} \mathrm{FS}_{\mathrm{it}}+\beta_{4} \mathrm{FA}_{\mathrm{it}}+\beta_{5} \mathrm{LV}_{\mathrm{it}}+\mathrm{e}_{\mathrm{it}}
$$

$\mathrm{GC}=$ Going concern evaluation

FOWN= Family ownership

BOWN $=$ Board of directors' ownership

FS $=$ Firm size

FA $=$ Firm age

$\mathrm{LV}=$ Leverage 


\section{Results and Analysis}

\subsection{Descriptive Statistics}

Tables 2 reports the descriptive statistics of variables used in analyzing the impact of ownership concentration on firm's going concern in Jordanian environment. The findings indicate that the overall firms have a mean going concern (GC) of 3.11 which is above the safe, with a maximum GC of 4.23 , and a minimum GC of 1.3, this result is higher and better than that reported in (B. Zureigat, Fadzil, \& Ismail, 2014a; B. Zureigat et al., 2014b). These different findings can be explained by the timing and the size of the samples in the respective research.

Regarding family ownership, (27\%) of the firms' equity is in the hands of families members. This proportion is very considerable because it implies that the family members have control over the firms. However, across the sample, the maximum value is $100 \%$ and the minimum value is $0 \%$, which means that some Jordanian listed companies are fully owned by family members. While for board of directors' ownership has an average of $40.8 \%$. However, the minimum value is $0 \%$ and the maximum value is $100 \%$, which implies that some Jordanian listed companies are fully owned by the board of directors. This result is compatible with Makhlouf et al. (2017), who found that the board of directors' ownership is (46\%). The average of total assets is (95468160) million Jordanian dinar. While the firms average age is 11 years. Also, average leverage (FLEV) is around $(0.36 \%)$.

Table 2. Descriptive statistics

\begin{tabular}{llllllll}
\hline Variable & Mean & STD & Max & Min & Skewness & Kurtosis & VIF \\
\hline GC & 3.11 & 0.44 & 1.23 & 1.3 & 1.32 & 2.08 & \\
FOWN & 0.27 & 1.67 & 1 & 0 & 1.06 & 2.36 & 3.89 \\
BOWN & 0.408 & 0.38 & 1 & 0 & 0.18 & -0.98 & 2.11 \\
FS & 95468160 & 1526894 & 1654814331 & 505334 & 6 & 28.35 & 1.02 \\
FA & 11 & 1.36 & 33 & 4 & 1.36 & 1.65 & 1.19 \\
LV & 0.31 & 0.326 & 2.35 & 0 & 1.02 & 1.36 & 1.09 \\
\hline
\end{tabular}

\subsection{Regression Results}

Numerous tests were undertaken to test the assumptions of panel data. Firstly, to check the normality, skewness and kurtosis values have been checked. The results in table 2 indicate that the data is normally distributed except in the firm size. Thus, it was transformed using the normal score to deal with the problems of non-normality of firm size. Secondly, the Variance inflation factor test (VIF) has been used to check multicollinearity problem. According to Gujarati (2009), if VIF > 10, this implies that there is high multicollinearity. Table 2 reports that the result of VIF values are not exceed 3.89, which is below the acceptable value of 10 . This implies the multicollinearity is not a problem in this research paper.

Thirdly, "to examine whether the data are sufficient and the results are not misleading, Heteroscedasticity and Autocorrelation tests have been used. To check for heteroscedasticity, "Modified Wald test" was used. While "Wooldridge test" has been undertaken to autocorrelation. The findings show that the model suffers from heteroscedasticity and autocorrelation problems. Thus, in this paper, cluster-robust standard errors were used to deal with heteroscedasticity and autocorrelation (Wooldridge, 2012). Finally, in order to select the appropriate model of panel data models (POLS, FEM or REM), "Breusch-Pagan LM test" was used to choose between the POLS model and random effect model (REM), while "Hausman test" was used to choose between the fixed effect model (FEM) and random effect model (REM). The finding in table 3 shows that the P-value is significant (P-value $<0.05$ ). Thus, the REM model is more suitable than POLS regression model. Furthermore, the findings of Hausman test indicate that the p-value is significant ( $p$-value $<0.05$ ); hence FEM is the best model for this study."

Table 3. Select between panel data models

\begin{tabular}{lll}
\hline & $\mathrm{Chi}^{2}$ & $\left(\right.$ Prob $\left.>\mathrm{chi}^{2}\right)$ \\
\hline LM Test & 8.26 & $(0.0000)$ \\
Hausman Test & 18.85 & $(0.0000)$ \\
\hline
\end{tabular}




\subsection{Multivariate Analysis}

The results of Table 4 report the impact of ownership concentration on firm's going concern. According to Hausman test, fixed effect model has been used with cluster-robust standard errors to remedy for heteroscedasticity and autocorrelation, as suggested by (Wooldridge, 2012). Moreover, the findings indicate that the F-statistic is significant, which means that the model has sufficiently describes the data and has reasonable explanatory ability regarding the effect of ownership concentration and going concern.

Table 4. Regression results of the relationship between ownership concentration and going concern

\begin{tabular}{lllll}
\hline Variables & Predict sign & Coefficients & t-Statistic & P-value \\
\hline Constant & & 18.26 & 2.195 & $0.0238^{* *}$ \\
FOWN & + & 10.843 & 7.844 & $0.0000^{* * *}$ \\
BOWN & + & 12.625 & 2.326 & $0.0077^{* * *}$ \\
FS & 10.851 & 1.214 & $0.0362^{* *}$ \\
FA & 8.651 & 1.240 & 0.1018 \\
LV & 7.355 & 0.966 & $0.0012^{* * *}$ \\
\hline Adjusted $\mathrm{R}^{2}$ & 0.5212 & & \\
F-statistic & & & \\
\hline ote. & $* * *, * * *$ indicates significance at the $10 \%, 5 \%, 1 \%$, levels.
\end{tabular}

As shown in table 4, the results reveal that family ownership is positively and significantly related to going concern. The finding is compatible with the direction of the first hypothesis. This finding implies that as family ownership increases, going concern opportunity will increase. This result is consistent with previous studies and could be attributed due to the nature of family-controlled firms, according to Noor Amran (2010); Villalonga and Amit (2006) family ownership can provide greater benefits to firms and lead to higher performance. This is because family members understand the company better than outside members and they are able to make superior decisions because they spend their working lives in the company they manage. Moreover, family members have a long-term vision of wealth creation compared to the short-term vision of hired CEOs (Chen et al., 2011). Furthermore, this finding is in the line with stewardship theory perspectives, which supposes that if family participation on the board is combined with family ownership, family members will be able to introduce a long-term vision of wealth creation and make crucial decisions.

With respect to the impact of directors' ownership on going concern, the results report that there is a positive and significant association between the existence of directors' ownership and going concern. This finding is consistent with the direction of the second hypothesis. The positive relationship implies that an increase in directors' ownership enhances the firm's going concern. This finding could be attributed due to the nature of the composition of boards of directors in Jordan, which most firms in Jordan are family-owned or controlled companies, where most of the shareholders prefer to manage the firms in which they own a proportion of stocks (Haddad et al., 2015; Makhlouf et al., 2017; Warrad et al., 2013). Moreover, this finding is compatible with the interest alignment hypothesis, which supposes that board ownership provides an incentive to maximize firm value and has a positive influence on firm performance (Makhlouf et al., 2017). The finding is also compatible with the agency theory perspective, which asserts that the directors' ownership is consider as an importance mechanism that gives the board members the power to act in the best interests of the company. This then mitigates the conflict of interest between the owners and the managers, which may reduce agency costs and enhancing performance.

As regards control variables, the findings indicate that there are positive and significant relationship between the firm size, leverage and going concern, but is insignificant with firm age.

\section{Conclusion}

This study aimed at enhances our understanding of the relationship between ownership concentration and going concern among Jordanian listed firms during 2013-2016. Ownership concentration was characterized by family ownership and board of directors' ownership. Going concern was measured using Altman's Z-Scores Model (1968). The findings indicate that the family ownership and directors' ownership is positively associated with going concern. The findings confirm the monitoring role of board of directors and family control in enhancing the firms going concern, noting to the positive impact of ownership concentration on firm going concern and in enhancing investors' confidence in financial reporting. Moreover, as family and directors' ownership increases, 
this considered as a motivation to the directors and family members to maximize their efforts to enhance firm performance and attract new resources to create a total surplus. In addition, these types of ownership structure plays a crucial role in reducing directors' opportunistic behaviour because the interests of all the stakeholders in the firm will be more aligned.

This study contributes to the literature on ownership concentration and going concern, as it sought to study whether the ownership concentration leads to improve the firm performance and provide great benefits to firm's continuity. Consequently, the outcomes of this study present considerable evidence from a developing country that contributes to the literature on the impact of ownership concentration on firm going concern in the Middle East region and Jordan particularly. Therefore, the findings of this research can be generalized to other countries that have similar cultural and economic considerations. Consequently, the findings this paper may have useful implications for regulators and policy-makers to enhance the transparency by issuing modern requirements to improve decision-making processes, and hence, to improve practices which support the going concern and improve transparency, accountability and disclosure.

This study is still subject to a few limitations. Firstly, the selection of firms is restricted to non-financial firms (industrial and service firms), while financial firms are excluded because these companies are subject to a different set of instructions and rules. Thus, it would be useful to for future studies to examine the impact of ownership concentration on going concern in the financial sector. Secondly, this study only investigated two types of ownership structure namely family ownership and directors' ownership because those types are most widespread in Jordan. Thus, it would be interesting to look at other types of ownership such as large shareholders, institutional ownership and government ownership in future research.

\section{References}

Al Dubai, S. A. A., Ismail, K. N. I. K., \& Amran, N. A. (2014). Family Involvement in Ownership, Management, and Firm Performance: Moderating and Direct-Effect Models. Asian Social Science, 10(14), p193.

Ali, S. M., Salleh, N. M., \& Hassan, M. S. (2008). Ownership structure and earnings management in Malaysian listed companies: the size effect. Asian Journal of Business and Accounting, 1(2), 89-116.

Altman, E. I. (1968). Financial ratios, discriminant analysis and the prediction of corporate bankruptcy. The journal of finance, 23(4), 589-609. https://doi.org/10.1111/j.1540-6261.1968.tb00843.x

Alves, S. (2012). Ownership structure and earnings management: Evidence from Portugal. Australasian Accounting Business \& Finance Journal, 6(1), 57-74.

Amran, N. (2010). Corporate Governance Mechanisims, Succession Planing And Firm Performance: Evidence From Malaysian Family And Nonfamily-Controlled Companies. (PhD Thesis), Universitu Utara Malaysia.

Amran, N., \& Ahmad, A. (2010). Family succession and firm performance among Malaysian companies. International Journal of Business and Social Science., 1(2), 193-203.

Anderson, R., \& Reeb, D. (2004). Board Composition: Balancing Family Influence in S\&P 500 Firms. Administrative Science 49(2), 209-237.

Bathula, H. (2008). Board Characteristics And Firm Performance: Evidence From New Zealand. (PhD thesis), Auckland University of Technology.

Becht, M., Bolton, P., \& Röell, A. (2002). Corporate Governance and Control. European Corporate Governance Institute. Retrieved from

Chen, E.-T., Gray, S., \& Nowland, J. (2011). Family involvement and family firm performance. City University of Hong Kong, China.

Davis, J. H., Schoorman, D. F., \& Donaldson, L. (1997). Toward A Stewardship Theory of Management Academy of Management Review, 22(1), 20-47.

Dyer, W. G. (2006). Examining the "family effect" on firm performance. Family Business Review, 19(4), 253-273. https://doi.org/10.1111/j.1741-6248.2006.00074.x

Elsayed, K. (2007). Does Ceo Duality Really Affect Corporate Performance? Corporate Governance: An International Review, 15(6), 1203-1214. https://doi.org/10.1111/j.1467-8683.2007.00641.x

Fama, E. F., \& Jensen, M. C. (1983). Separation of ownership and control. Journal of Law and Economics, 26(2), 301-325. https://doi.org/10.1086/467037

Gujarati, D. N. (2009). Basic Econometrics (5th ed.). New York: McGraw-Hill. 
Habbash, M. (2010). The Effectiveness of Corporate Governance and External Audit on Constraining Earnings Management Practice in the UK. (PhD thesis), Durham University. Retrieved from http://etheses.dur.ac.uk/448/

Haddad, A. E., AlShattarat, W. K., AbuGhazaleh, N. M., \& Nobanee, H. (2015). The Impact Of Ownership Structure And Family Board Domination On Voluntary Disclosure For Jordanian Listed Companies. Eurasian Business Review, 5(2), 203-234.

Hashim, H. A. (2009). Board of directors, ownership structure, ethnicity and earnings quality: Malaysian evidence. University of Malaya.

Horner, S. V. (2010). Board Power, CEO Appointments And CEO Duality Academy of Strategic Management Journa, 9(2), 43-58.

Iskandar, T. M., Rahmat, M. M., Noor, N. M., Saleh, N. M., \& Ali, M. J. (2011). Corporate governance and going concern problems: evidence from Malaysia. International Journal of Corporate Governance, 2(2), 119-139. https://doi.org/10.1504/IJCG.2011.041151

Jensen, M. C., \& Meckling, W. H. (1976). Theory of the firm: managerial behavior, agency costs and ownership structure. Journal of Financial Economics, 3(4), 305-360. https://doi.org/10.1016/0304-405X(76)90026-X

Makhlouf, M. H., Al-Sufy, F. J., \& Almubaideen, H. (2018). Board Diversity and Accounting Conservatism: Evidence from Jordan. International Business Research, 11(7), 130-141. https://doi.org/10.5539/ibr.v11n7p130

Makhlouf, M. H., Laili, N. H., Ramli, N. A., \& Basah, M. Y. (2017). Board of Directors' Effectiveness and Firm Performance: Evidence from Jordan. Research Journal of Finance and Accounting, 8(18), 23-34.

Oluku, M. D. (2017). Ownership Structure and Earnings Management Practices of Nigerian Companies. The Journal of Internet Banking and Commerce, 22(S8), 1-8.

Parker, S., Peters, G. F., \& Turetsky, H. F. (2005). Corporate governance factors and auditor going concern assessments. Review of Accounting and Finance, 4(3), 5-29. https://doi.org/10.1108/eb043428

Pedro Sánchez Ballesta, J., \& Garcia-Meca, E. (2005). Audit qualifications and corporate governance in Spanish listed firms. Managerial Auditing Journal, 20(7), 725-738. https://doi.org/10.1108/02686900510611258

Ramadan, I. Z. (2016). Does Ownership Structure Affect Jordanian Companies' Tendency to Practice Earnings Management? Asian Journal of Finance \& Accounting, 7(2), 281-291. https://doi.org/10.5296/ajfa.v7i2.8537

Saleem Salem Alzoubi, E. (2016). Ownership structure and earnings management: evidence from Jordan. International Journal of Accounting \& Information Management, 24(2), 135-161. https://doi.org/10.1108/IJAIM-06-2015-0031

Stigler, G. J., \& Friedland, C. (1983). The Literature of Economics: The Case of Berle and Means. Journal of law and Economics, 26(2), 237-268. https://doi.org/10.1086/467032

Sunusi Garba, M. M. (2017, 18-20 Sept.). Board Ownership and Going-concern of Nigerian Listed Banks: The Role of Audit Committee Financial Expertise. Paper presented at the International Conference on Accounting Studies (ICAS), Putrajaya, Malaysia.

Villalonga, B., \& Amit, R. (2006). How Do Family Ownership, Control And Management Affect Firm Value? Journal of Financial Economics, 385-417. https://doi.org/10.1016/j.jfineco.2004.12.005

Vo, D., \& Phan, T. (2013). Corporate governance and firm performance: emperical evidence from Vitenam. Journal of Economic Development, 62-78.

Warrad, L., Almahamid, S. M., Slihat, N., \& Alnimer, M. (2013). The relationship between ownership concentration and company performance, a case of Jordanian non-financial listed companies. Institute of Interdisciplinary Business Research.

Watkins-Fassler, K., Fernández-Pérez, V., \& Rodríguez-Ariza, L. (2017). President interlocking, family firms and performance during turbulent times: Evidence from Latin America. European Journal of Family Business.

Wooldridge, J. M. (2012). Introductory Econometrics: A Modern Approach (5th ed.). USA: Cengage Learning.

Zureigat, B., Fadzil, F. H., \& Ismail, S. S. S. (2014a). The Relationship between Corporate Governance Mechanisms and Going Concern Evaluation: Evidence from Firms Listed on Amman Stock Exchange. 
Journal of Public Administration and Governance, 4(4), 100-110. https://doi.org/10.5296/jpag.v4i4.6745

Zureigat, B., Fadzil, F. H., \& Ismail, S. S. S. (2014b). The Role of Foreign, Family Ownership and Audit Committee in Evaluating the Company as a Going Concern: Evidence from Jordan. International Journal of Accounting and Financial Reporting, 4(2), 329-338. https://doi.org/10.5296/ijafr.v4i2.6486

Zureigat, Q. (2011). The Effect of Ownership Structure on Audit Quality: Evidence from Jordan. International Journal of Business and Social Science, 22(10), 38-46.

\section{Copyrights}

Copyright for this article is retained by the author(s), with first publication rights granted to the journal.

This is an open-access article distributed under the terms and conditions of the Creative Commons Attribution license (http://creativecommons.org/licenses/by/4.0/). 